\title{
MIR127 Gene
}

National Cancer Institute

\section{Source}

National Cancer Institute. MIR127 Gene. NCI Thesaurus. Code C80754.

This gene is involved in the regulation of gene expression and plays a role in the development of hepatocellular, colon, bladder, breast and prostate carcinomas. 